University of Nebraska - Lincoln

DigitalCommons@University of Nebraska - Lincoln

2016

\title{
AN ASSESSMENT OF FEDERAL OUTLAY ON PIVOTAL GROWTH INDUCED SECTORS IN NIGERIA
}

\author{
Samson Adeniyi Aladejare \\ Federal University, Wukari, Nigeria \\ Eche Emmanuel \\ Federal University, Wukari, Nigeria \\ Charles Edobor Umonda \\ Federal University, Wukari, Nigeria
}

Follow this and additional works at: https://digitalcommons.unl.edu/jade

Part of the Econometrics Commons, Growth and Development Commons, International Economics Commons, Political Economy Commons, Public Economics Commons, and the Regional Economics Commons

Aladejare, Samson Adeniyi; Emmanuel, Eche; and Umonda, Charles Edobor, "AN ASSESSMENT OF FEDERAL OUTLAY ON PIVOTAL GROWTH INDUCED SECTORS IN NIGERIA" (2016). Journal for the Advancement of Developing Economies. 1.

https://digitalcommons.unl.edu/jade/1

This Article is brought to you for free and open access by the Economics Department at DigitalCommons@University of Nebraska - Lincoln. It has been accepted for inclusion in Journal for the Advancement of Developing Economies by an authorized administrator of DigitalCommons@University of Nebraska - Lincoln. 


\title{
An Assessment of Federal Outlay on Pivotal Growth Induced Sectors in Nigeria
}

\author{
Samson Adeniyi Aladejare, Eche Emmanuel, Charles Edobor Umonda \\ Federal University Wukari, Nigeria
}

\begin{abstract}
This study analyses government capital and recurrent spending outlays on sectors (education, health, defense agriculture and transport and communication) believed to be critical to the growth of the economy, for the period 1980 to 2014. The Error Correction Method was adopted to analyze the short-run impact of each spending division on the prosperity of the economy. The disaggregation into capital and recurrent expenditure was done to gauge the impact each has economic growth. Empirical findings of the study reveal that though capital outlays on the sectors concerned have been more significant than recurrent spending towards achieving the goal of economic growth, more priority should still be given to capital spending. At the same time, the continuous growth in recurrent spending over capital spending should be checked. This study therefore recommends an increase capital spending in the various sectors considered, relative to recurrent spending, in accordance with our conclusions drawn from the period under study. We believe the main critical inducing outlay of government on growth is capital spending. Also, because of the interrelationship existing between the sectors considered, proper harnessing of the potentials of the various sectors is crucial towards attaining the goal of Nigeria becoming one of the twenty most industrialized nations by 2020,
\end{abstract}

Keywords: Education, Health, Transport and Communication, Defense, Agriculture.

\section{INTRODUCTION}

It is believed that today's government provides a wide range of services through the budget. Such services can be said to include the provision of economic and social infrastructure, defense, maintenance of law and order, establishment of pension schemes, etc. The level of government's participation in providing goods and services is subject to space and time variations. The scope of government functions depends, among other things, on the political and economic orientation of the members of a particular society at a given point in time, as well as their needs and aspirations (Adesola 1995). The performance or discharge of these functions engenders governmental fiscal operations.

In 2006, President Obasanjo made an assertion when delivering his budget speech to a joint session of the national assembly, in which he stated that the building blocks for the diversification of the Nigerian economy and the primary sources of growth are agriculture, manufacturing, solid minerals, and construction: an assertion which is believed to be true. In other words, accelerating the pace of growth and development of the agricultural, manufacturing, mining (solid minerals), 
education, healthcare, and other non-oil sectors will lead to faster integration and improvement in the welfare of the vast majority of the population of Nigeria.

The size and role of the government in a country have been explored from different perspectives in the economic literature. The existence of an optimal government share in the economy has been subject to considerable theoretical debate and sustained empirical assessment. In particular, the literature has provided possible determinants for the different size of government across countries. These kinds of studies, in general, focus on different single aspects, which are supposed to be the driving force of the overall government size with respect to GDP.

\section{EMPIRICAL REVIEW}

Over time, various studies have been carried out to examine the relationship between government spending and economic growth, some of which include the following.

Nitoy, et al. (2003), employed a disaggregated approach in examining the growth effects of government expenditure for a panel of thirty developing countries (including Nigeria) in the 1970s and 1980 s, with special interest placed on sectoral expenditures. Their resulting findings revealed that the share of government capital expenditure in GDP is positively and significantly correlated with economic prosperity, but the coefficient for recurrent outlay was found to be insignificant. The result of the analysis at the sectoral level shows that government investment and total expenditures on education are the only outlays that remain significantly associated with growth. Although public investments and expenditures in sectors such as transport, communication, and defense were found to be significantly correlated with growth initially, they rarely survive when government budget constraint and other sectoral expenditures were built into the analysis. In addition, private investment share of GDP was found to be associated with economic growth in a significant and positive manner.

Josaphat, et al. (2000), examined the impact of government spending has on economic growth in Tanzania for the time frame of 1965 to 1996, using time series data from the 32-year period. They developed a simple growth accounting model, developed after the Ram (1986) model in which total government expenditure is disaggregated into expenditure on (physical) investment, consumption spending, and human capital investment. It was found that increased productive expenditure (physical investment) has an inverse effect on growth; while consumption expenditure correlate positively to growth, and which in particular appears to be associated with increased private consumption. Their empirical findings show an insignificant outlay on human capital investment and affirm the view that public investment in Tanzania has not been productive.

Nigerian public expenditures can broadly be categorized into capital and recurrent expenditure. Recurrent expenditure is government expenses on administration which include wages, salaries, interest on loans, maintenance, etc., while expenses on capital projects like roads, airports, education, telecommunication, electricity generation, etc., are referred to as capital expenditure. One of the main goals of government spending is to ensure availability of infrastructural facilities for development purpose. Over the past decades, there has been an exponential increase in public sector spending through different government responsibilities and interactions with its Ministries, Departments and Agencies (MDA's), (Niloy et al. 2003). Although, the widely perceived opinion 
is that public expenditure, either recurrent or capital, and especially on social and economic infrastructure, can be growth-enhancing, in reality, the financing of such expenditure to provide essential infrastructural facilities, including transport, electricity, telecommunications, water and sanitation, waste disposal, education and health can be growth- retarding (for example, the negative effect associated with taxation and excessive debt). The size and structure of public expenditure will determine the pattern and form of growth in output of the economy.

Robinson, et al. (2014), examined the relationship between government expenditures and economic growth in Nigeria from 1980 to 2010. The study disaggregated Government Expenditure into total expenditure, public debt expenditure, expenditure on health, and government expenditure on Education. The ordinary least square (OLS) method was applied to ascertain the short run relationship between variables. Meanwhile, the Augmented Dickey Fuller (ADF) test was used to gauge the long-run relationship between the variables. Results of the test reveal that there is a negative relationship between economic growth and government expenditures on health, while government expenditures in the education sector were found to be insufficient for the expending sector in Nigeria. It was also discovered that government expenditures in Nigeria could increase foreign and local investments. Their study recommends that government should spend more on key macro-variables, such as health, infrastructure, power, etc. They believe that judicious expenditure by the government will power the transformation agenda of the government, as well as engender growth in the Nigerian economy.

Maku (2014) studied the link between government spending and economic growth in Nigeria over the period 1977 to 2006, using time series data to analyze the Ram (1986) model. Three variants of the Ram model were developed, regressing Real GDP versus Private investment, Human capital investment, Government investment, and Consumption spending at absolute levels. The regression took real GDP as a share of real output, as well as the growth rate of real output to the explanatory variable as a share of real GDP, in order to capture the precise link between public investment spending and economic growth in Nigeria, based on different levels. Empirical results of the study showed that private and public investments have insignificant effect on economic growth. With the use of an error-correction model to detect short run behavior of the variables, the result shows that for any distortion in the short run, the error term restores the relationship back to its original equilibrium by a unit. The paper's main policy recommendation was that government spending should be channeled in order to influence economic growth significantly and positively in Nigeria, especially on education and infrastructural facilities.

\section{STUDY METHODOLOGY}

The study methodology adopted is the Error Correction Method (ECM), which was first adopted by Sargan and later emphasized by Engle and Granger to control for equilibrium. An essential theorem known as the Granger representation theorem states that if two variables $Y$ and $X$ are cointegrated, then the relationship between the two can be expressed as ECM.

The variables of interest used in this study are: per capita gross domestic product (PCGDP) used as proxy to measure the growth rate of the economy, defense spending (DEFN), education outlay (EDUCA), health spending (HELTH), agricultural spending (AGRIC), transportation and communication (TRACOMM), and total federally collected revenue (TFCR) which is used as a 
control variable. Data were sourced from Central Bank of Nigeria's statistical bulletin for various years; as well as from the concerned federal ministries' online databases.

Two ECM models were estimated for the study as shown below. The first model captures the short run behavior of capital outlays for growth-inducing sectors on the GDP per capita variable. The second equation captures the effect of recurrent outlays for growth inducing sectors also on the GDP per capita variable.

\section{Model 1:}

$d \log (P C G D P)=\beta_{0}+d \beta_{1} \log (D E F N)+d \beta_{2} \log (E D U C A)+d \beta_{3} \log (H E L T H)+$ $d \beta_{4} \log (A G R I C)+d \beta_{5} \log ($ TRACOMM $)+d \beta_{6} \log ($ TFCR $)+d \beta_{7} \log \left(\right.$ PCGDP $\left._{t-1}\right)+$ $d \beta_{8} \log \left(D E F N_{t-1}\right)+d \beta_{9} \log \left(E D U C A_{t-1}\right)+d \beta_{10} \log \left(H E L T H_{t-1}\right)+d \beta_{11} \log \left(A G R I C_{t-1}\right)+$ $d \beta_{12} \log \left(\right.$ TRACOMM $\left._{t-1}\right)+d \beta_{13} \log \left(\right.$ TFCR $\left._{t-1}\right)+\varphi_{1} E C M_{t-1}+\varepsilon_{1}$

Where:

$\mathrm{d}=$ indicates first difference or short run factor

$\varepsilon=$ white noise error term

$\beta_{1}$ to $\beta_{13}=$ parameter estimates

$\varphi_{1}=$ error correction speed of adjustment parameter

Log $=$ logarithm transformation

$\mathrm{t}-1$ = lagged by one variable.

\section{Model 2:}

$$
\begin{aligned}
& d \log (P C G D P)=\alpha_{0}+d \alpha_{1} \log (D E F N)+d \alpha_{2} \log (E D U C A)+d \alpha_{3} \log (H E L T H) \\
& +d \alpha_{4} \log (A G R I C)+d \alpha_{5} \log (\text { TRACOMM })+d \alpha_{6} \log (T F C R) \\
& +d \alpha_{7} \log \left(P C G D P_{t-1}\right)+d \alpha_{8} \log \left(D E F N_{t-1}\right)+d \alpha_{9} \log \left(E D U C A_{t-1}\right) \\
& +d \alpha_{10} \log \left(H E L T H_{t-1}\right)+d \alpha_{11} \log \left(\text { AGRIC }_{t-1}\right)+d \alpha_{12} \log \left(\text { TRACOMM }_{t-1}\right) \\
& +d \alpha_{13} \log \left(T F C R_{t-1}\right)+\varphi_{2} E C M_{t-1}+\varepsilon_{2}
\end{aligned}
$$

Where:

$\mathrm{d}=$ indicates first difference or short run factor

$\varepsilon=$ white noise error term

$\alpha_{1}$ to $\alpha_{13}=$ are parameter estimates

$\varphi_{1}=$ error correction speed of adjustment parameter $\log =$ logarithm transformation

$\mathrm{t}-1$ = lagged by one variable.

The methodology employed in deriving the preferred short run dynamic model is the general to specific approach. We start with a general error correction model, which includes lags up to the fourth order. This general model is then tested by using a priori expectations and statistical significance tests in order to arrive at a parsimonious preferred short run dynamic specification. The parsimonious result for the model is presented in table 3 below.

\subsection{Unit Root Test}

Due to the nature of most time series data, it is imperative to conduct a unit root test on the series in the ECM model. This study made use of the Augmented Dickey Fuller (ADF) test, and the 
Kwiatkowski-Phillips-Schmidt-Shin (KPSS) unit root testing procedure to ascertain the level of stationarity of the series.

\subsection{Model One Result Analyses}

\subsubsection{Unit Root Analysis for Model One}

Table 2: Unit Root Test for model 1 at first difference. Ho: There is unit root

\begin{tabular}{|c|c|c|c|c|c|}
\hline Variables & ADF-Test & & KPSS-Test & & Conclusion \\
\hline & At Constant & $\begin{array}{l}\text { Constant and } \\
\text { Trend }\end{array}$ & At Constant & $\begin{array}{l}\text { Constant and } \\
\text { Trend }\end{array}$ & \\
\hline Log(PCGDP) & $-4.262946 * *$ & $-4.946335 * *$ & $0.506478 * * *$ & $0.083809 * *$ & $\mathrm{NO}$ \\
\hline $\log (\mathrm{DEFN})$ & $-9.535907 * *$ & $-6.449704 * *$ & $0.026781 * *$ & $0.027552 * *$ & $\mathrm{NO}$ \\
\hline Log(EDUCA) & $-6.705189 * *$ & $-6.637319 * *$ & $0.152125^{* *}$ & $0.076376^{* *}$ & $\mathrm{NO}$ \\
\hline $\log ($ HELTH $)$ & $-8.856112 * *$ & $-8.707406^{* *}$ & $0.096045^{* *}$ & $0.096371 * *$ & $\mathrm{NO}$ \\
\hline Log(TRACOMM) & $-7.340729 * *$ & $-7.139828 * *$ & $0.088610 * *$ & $0.076589 * *$ & $\mathrm{NO}$ \\
\hline $\log (\mathrm{TFCR})$ & $-6.276573 * *$ & $-3.475030^{*}$ & $0.194436^{* *}$ & $0.134190 * *$ & $\mathrm{NO}$ \\
\hline
\end{tabular}

Source: Computed by Authors from Eviews Output.

NOTE: $*, * *, * * *$ represents significance levels at $10 \%, 5 \%$ and $1 \%$ respectively.

YES- Indicates the presence of unit root in the series.

NO - Indicates the absence of unit root in the series.

The ADF and KPSS unit root test result for model one in Table 2 reveals that the series are stationary at their first difference. Thus, the null hypothesis of unit root presence is being rejected at the 5 percent level of significance.

\subsubsection{Cointegration Test Result for Model One}

The cointegration test result for the models are presented below

\section{Table 3: Unrestricted Cointegration Rank Test (Trace)}

\begin{tabular}{|l|c|c|c|c|}
\hline $\begin{array}{l}\text { Hypothesized No. } \\
\text { of CE(s) }\end{array}$ & Eigenvalue & Trace Statistic & 0.05 Critical Value & Prob. Value \\
\hline None* & 0.981188 & 301.2984 & 125.6154 & 0.0000 \\
\hline At most 1 & 0.941782 & 186.0736 & 95.75366 & 0.0000 \\
\hline At most 2 & 0.786416 & 103.6101 & 69.81889 & 0.0000 \\
\hline At most 3 & 0.743600 & 58.84205 & 47.85613 & 0.0033 \\
\hline
\end{tabular}

Trace test indicates 4 cointegrating equation at the 0.05 level of significance.

*, Denotes rejection of the hypothesis at the 0.05 level of significance

**, represents Mackinnon-Haug-Michelis (1999) P-values.

Source: Computed by Authors from Eviews Output

The Trace test and maximum Eigenvalue values in table 3 and 4, respectively, show that four cointegrating equations exist in the model. This test shows that the fiscal capital variables of interest do have a long run relationship. 
Table 4: Unrestricted Cointegration Rank Test (Maximum Eigenvalue)

\begin{tabular}{|l|c|c|c|c|}
\hline $\begin{array}{l}\text { Hypothesized No. } \\
\text { of CE(s) }\end{array}$ & Eigenvalue & Max-Eigen Statistic & 0.05 Critical Value & Prob. Value \\
\hline None* & 0.981188 & 115.2248 & 46.23142 & 0.0000 \\
\hline At most 1 & 0.941782 & 82.46351 & 40.07757 & 0.0000 \\
\hline At most 2 & 0.786416 & 44.76801 & 33.87687 & 0.0017 \\
\hline At most 3 & 0.743600 & 39.46950 & 27.58434 & 0.0010 \\
\hline
\end{tabular}

Max- eigenvalue test indicates 4 cointegrating equations at the 0.05 level.

*, Denotes rejection of the hypothesis at the 0.05 level of significance

**, represents Mackinnon-Haug-Michelis (1999) P-values.

Source: Computed by Authors from Eviews Output

\subsubsection{ECM Result Analysis for Model One}

Table 5: ECM for Model One.

\begin{tabular}{|l|l|l|l|l|}
\hline Dependent Variable: & \multicolumn{2}{l|}{ dlog(PCGDP) } & T-Statistic & Prob. \\
\hline $\begin{array}{l}\text { Independent } \\
\text { Variable }\end{array}$ & Coefficient & Std. Error & & \\
\hline Dlog(Pcgdp(-1)) & 0.546638 & 0.189599 & 2.883128 & 0.0095 \\
\hline Dlog(Agric) & 0.029827 & 0.015496 & 1.924771 & 0.0694 \\
\hline Dlog(Defn) & -0.035495 & 0.018573 & -1.911084 & 0.0712 \\
\hline Dlog(Educa) & 0.018680 & 0.022181 & 0.842162 & 0.4102 \\
\hline Dlog(Tfcr) & -0.058480 & 0.046422 & -1.259744 & 0.2230 \\
\hline Dlog(Agric(-1)) & -0.037681 & 0.019394 & -1.942892 & 0.0670 \\
\hline Dlog(Educa(-1)) & -0.041029 & 0.023492 & -1.746508 & 0.0969 \\
\hline Dlog(Helth(-1)) & -0.011755 & 0.017154 & -0.685286 & 0.5014 \\
\hline Dlog(Tracomm(-1)) & 0.024241 & 0.015967 & 1.518171 & 0.1454 \\
\hline & & & & \\
\hline \multicolumn{1}{|c|}{ C } & 0.026432 & 0.014946 & 1.768554 & 0.0930 \\
\hline ECM(-1) & -0.149335 & 0.103664 & -1.440563 & 0.1660 \\
\hline R-squared & 0.547705 & Adj R-sqaured & 0.309655 & \\
\hline F-statistic & 2.300801 & Prob(F-statistic) & 0.056651 & \\
\hline Source: Comput & & \\
\hline
\end{tabular}

Source: Computed by Authors from Eviews Output

The short run model results contained in table 5 for model one support, to a large extent, earlier assertions that fiscal outlays by government are actually the main drivers of growth in any economy. From the result, current growth in the economy is significantly impacted upon by previous year recorded improvements in economic growth. This behavior likely occurs because as the economy records growth; policy makers would ensure that such economic achievements are sustained in the future.

Similarly, capital spending in the agricultural sector positively stimulates economic growth in the same period. This can be attributed to government's yearly effort at making fertilizers available, as well as providing credit to farmers, building grain storage facilities, etc. However, previous year capital investment in the sector have a significantly negative impact on the economy. A factor responsible for this is the use of capital investment to import agricultural products instead of improving exports. 
Capital spending in the defense sector has a significant, negative impact on the growth of the economy. This shows that the allocation of funds to purchase military hardware and military construction crowds out funds for development of other sectors in the short run.

Capital spending on education in the current period positively impacts economic growth, but its contribution is not found to be significant. Conversely, previous investment in the sector significantly and negatively impacts the economy. The cases of strikes and high rates of abandoned projects in the sector can be pointed to as responsible factors for these results. This therefor means that more funding of the sector, smooth running of the sector, and commitments at fulfilling all abandoned projects are actually needed by policy makers. In a similar response, capital funding in the health sector in the previous period does not have positive influence on economic growth. This can also be linked to the poor funding of the sector as well as short fall in manpower in the sector. Investment in transport and communication by the government, though, shows a positive impact on the economy, but the influence is insignificant. An improved funding of the sector to finance roads, network provisions, and the availability of modern transportation for the citizens is capable of turning the tide.

The ECM coefficient of -0.15 shows that an annual correction of about 15 percent takes place in the economy in the presence of distortion to long run equilibrium. This means for long run equilibrium to be restored in the system as a result of policy and political distortions; it would take about six years and seven months for the effect of the distortion to be neutralized or erased.

\subsubsection{ECM Result Analysis for Model One}

\section{Model One Normality Test}

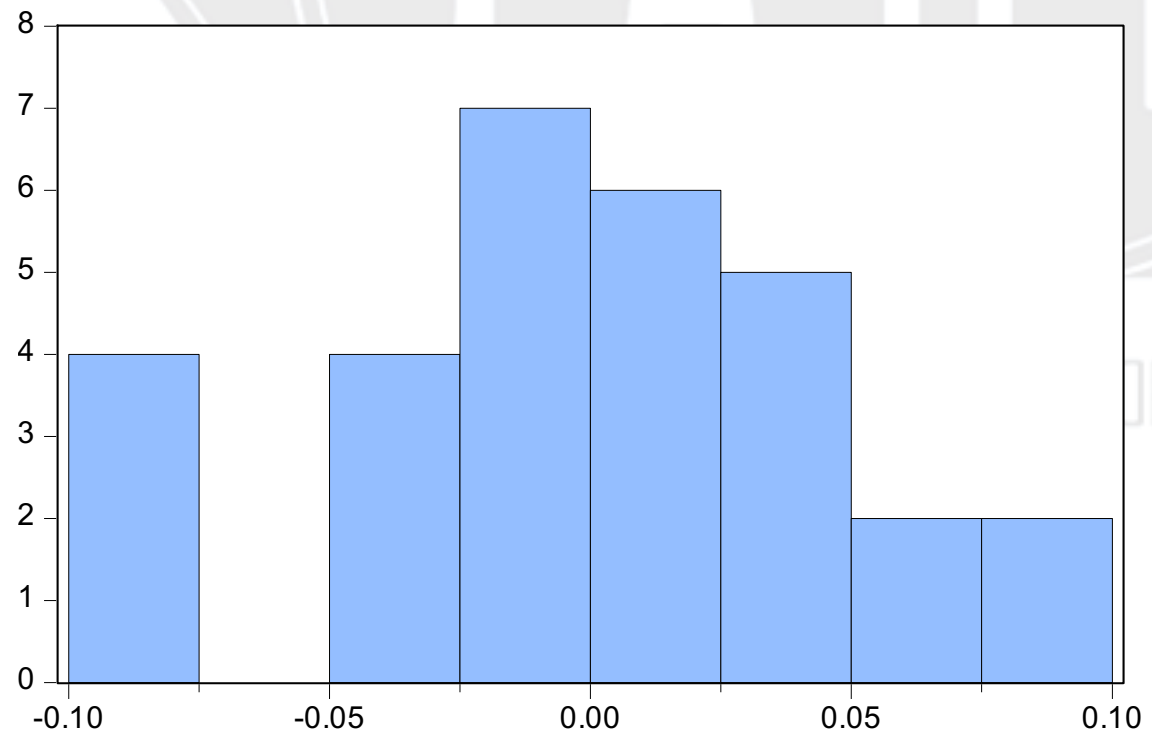

\begin{tabular}{|lr|}
\hline \multicolumn{2}{|l}{ Series: Residuals } \\
Sample 1983 2014 \\
Observations 30 \\
Mean & $5.09 \mathrm{e}-18$ \\
Median & 0.001020 \\
Maximum & 0.095887 \\
Minimum & -0.084953 \\
Std. Dev. & 0.046890 \\
Skewness & -0.034573 \\
Kurtosis & 2.566977 \\
& \\
Jarque-Bera & 0.240362 \\
Probability & 0.886760 \\
\hline
\end{tabular}

Figure 1: Normality Test for model one

Source: Computed by Authors from Eviews Output

The residual normality test above accepts the null hypothesis that the residuals for model one is normally distributed. 


\section{Model One Serial Correlation Test}

Table 6: Breusch-Godfrey Serial Correlation LM Test:
F-statistic
0.398804 Prob. F(2,17)
0.6772
Obs*R-squared
1.344463 Prob. Chi-Square(2)
0.5106

Source: Computed by Authors from Eviews Output

Likewise, the serial correlation test for model one also accepts the null hypothesis of no serial correlation in the residuals.

\section{Model One Heteroscedasticity Test}

Table 7: Heteroskedasticity Test: Breusch-Pagan-Godfrey

\begin{tabular}{llll}
\hline F-statistic & 1.254243 & Prob. F(10,19) & 0.3211 \\
Obs*R-squared & 11.92910 & Prob. Chi-Square(10) & 0.2898 \\
Scaled explained SS & 3.748912 & Prob. Chi-Square(10) & 0.9580
\end{tabular}

Source: Computed by Authors from Eviews Output

In line with the above tests (accepting the null hypothesis) and judging by the probability value of the observed R-squared, the residuals for model one show that they are homoscedastic in nature.
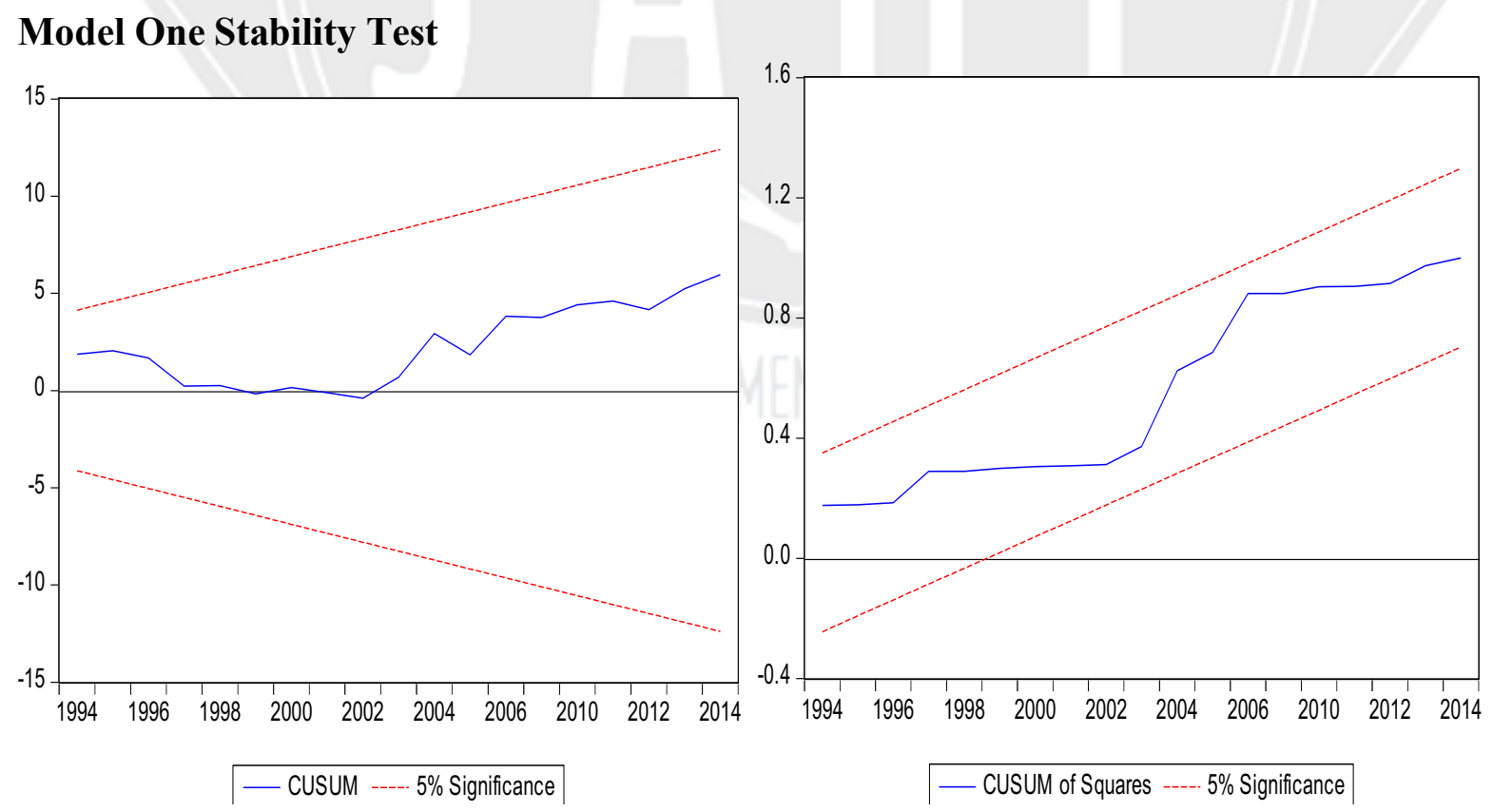

Figure 2: Residual Stability Test

Source: Computed by Authors from Eviews Outp 
The residual stability test for cumulative sum and cumulative sum squared shows that the residuals are stable at the five percent significance level.

\subsection{Model One Result Analyses}

\subsubsection{Unit Root Test Analysis}

Table 8: Unit Root Test for model 2 at first difference. Ho: There is unit root

\begin{tabular}{|c|c|c|c|c|c|}
\hline Variables & ADF-Test & & KPSS-Test & & Conclusion \\
\hline & At Constant & $\begin{array}{l}\text { Constant and } \\
\text { Trend }\end{array}$ & At Constant & $\begin{array}{l}\text { Constant and } \\
\text { Trend }\end{array}$ & \\
\hline $\log ($ PCGDP) & $-4.262946^{* *}$ & -4.946335 & $0.506478 * * *$ & $0.083809 * *$ & $\mathrm{NO}$ \\
\hline $\log (\mathrm{DEFN})$ & $-7.305213 * *$ & $-7.193043^{* *}$ & $0.134747^{* *}$ & $0.126067 * *$ & $\mathrm{NO}$ \\
\hline $\log ($ EDUCA) & $-5.103092 * *$ & -5.355479 & $0.269548 * *$ & $0.228643 * *$ & $\mathrm{NO}$ \\
\hline $\log ($ HELTH $)$ & $-5.165153^{* *}$ & $-5.118281 * *$ & $0.469584 * * *$ & 0.469295 & $\mathrm{NO}$ \\
\hline $\log (\mathrm{TRACOMM})$ & $-7.369832 * *$ & $-7.355713^{* *}$ & $0.263891^{* *}$ & $0.237331 * * *$ & $\mathrm{NO}$ \\
\hline $\log (\mathrm{TFCR})$ & $-6.276573 * *$ & $-3.475030 *$ & $0.194436^{* *}$ & $0.134190^{* *}$ & $\mathrm{NO}$ \\
\hline
\end{tabular}

Source: Computed by Authors from Eviews Output.

NOTE: *,**,*** represents significance levels at $10 \%, 5 \%$ and $1 \%$ respectively.

YES- Indicates the presence of unit root in the series.

NO - Indicates the absence of unit root in the series.

Table 8 unit root test shows that all of the variables for model 2 are also found to be stationary at their first difference form, confirming that all the variables are integrated of order one; i.e I(1).

\subsubsection{Cointegration Test Result for Model Two}

The cointegration test result for the models are presented below.

Table 9: Unrestricted Cointegration Rank Test (Trace)

\begin{tabular}{|l|c|c|c|c|}
\hline $\begin{array}{l}\text { Hypothesized No. } \\
\text { of CE(s) }\end{array}$ & Eigenvalue & Trace Statistic & $\mathbf{0 . 0 5}$ Critical Value & Prob. Value \\
\hline None* & 0.835088 & 169.3850 & 125.6154 & $0.0000^{* *}$ \\
\hline At most 1 & 0.696960 & 111.7099 & 95.75366 & 0.0026 \\
\hline At most 2 & 0.534560 & 73.50546 & 69.81889 & 0.0246 \\
\hline At most 3 & 0.498228 & 49.03272 & 47.85613 & 0.0386 \\
\hline
\end{tabular}

Trace test indicates 4 cointegrating equation at the 0.05 level of significance.

$*$, Denotes rejection of the hypothesis at the 0.05 level of significance

**, represents Mackinnon-Haug-Michelis (1999) P-values.

Source: Computed by Authors from Eviews Output

Table 10: Unrestricted Cointegration Rank Test (Maximum Eigenvalue)

\begin{tabular}{|l|c|c|c|c|}
\hline $\begin{array}{l}\text { Hypothesized No. } \\
\text { of CE(s) }\end{array}$ & Eigenvalue & $\begin{array}{l}\text { Max-Eigen } \\
\text { Statistic }\end{array}$ & 0.05 Critical Value & Prob. Value \\
\hline None* & 0.835088 & 57.67502 & 46.23142 & 0.0021 \\
\hline At most 1 & 0.696960 & 38.20448 & 40.07757 & 0.0801 \\
\hline At most 2 & 0.534560 & 24.47274 & 33.87687 & 0.4215 \\
\hline At most 3 & 0.498228 & 22.06749 & 27.58434 & 0.2169 \\
\hline
\end{tabular}

Max- eigenvalue test indicates 1 cointegrating equation at the 0.05 level of significance.

*, Denotes rejection of the hypothesis at the 0.05 level of significance

**, represents Mackinnon-Haug-Michelis (1999) P-values. Source: Computed by Authors from Eviews Output 
Similarly, the Trace and Max-Eigenvalues for the recurrent fiscal variables in table 11 and 12 reveal the presence of four and one cointegrating equations, respectively, at the five percent significant level. This also shows that the fiscal series do have a long run relationship.

\subsubsection{ECM Result Analysis for Model Two}

Table 11: ECM for Model Two.

\begin{tabular}{|l|l|l|l|l|}
\hline Dependent Variable: & \multicolumn{2}{|c|}{ dlog(PCGDP) } & T-Statistic & Prob. \\
\hline $\begin{array}{l}\text { Independent } \\
\text { Variable }\end{array}$ & Coefficient & Std. Error & & \\
\hline Dlog(Pcgdp(-1)) & 0.216838 & 0.215231 & 1.007465 & 0.3264 \\
\hline Dlog(Educa) & -0.013943 & 0.045300 & -0.307784 & 0.7616 \\
\hline Dlog(Agric) & -0.012599 & 0.023769 & -0.530044 & 0.6022 \\
\hline Dlog(Tfcr) & 0.061112 & 0.042148 & 1.449944 & 0.1634 \\
\hline Dlog(Helth) & 0.026123 & 0.048392 & 0.539815 & 0.5956 \\
\hline Dlog(Tracomm) & -0.036592 & 0.018910 & -1.935088 & 0.0680 \\
\hline Dlog(Defn(-1)) & -0.089611 & 0.039534 & -2.266702 & 0.0353 \\
\hline Dlog(Educa(-1)) & -0.016790 & 0.042048 & 0.399315 & 0.6941 \\
\hline Dlog(Helth(-1)) & -0.019534 & 0.045315 & -0.431081 & 0.6713 \\
\hline Dlog(Tfcr(-1)) & 0.058858 & 0.047431 & 1.240915 & 0.2297 \\
\hline Dlog(Tracomm(-1)) & 0.004935 & 0.018178 & 0.271468 & 0.7890 \\
\hline \multicolumn{1}{|c|}{ C } & 0.009602 & 0.018852 & 0.509323 & 0.6164 \\
\hline ECM(-1) & -0.153782 & 0.102406 & -1.501688 & 0.1496 \\
\hline R-squared & 0.446577 & Adj R-squared & 0.097047 & \\
\hline F-statistic & 1.277649 & Prob(F-statistic) & 0.306601 & \\
\hline
\end{tabular}

Source: Computed by Authors from Eviews Output

The ECM result for model two which shows the relationship between recurrent outlays and economic growth is presented in the above table. The results show that same-period recurrent spending in the education and agriculture sectors negatively affect growth, though the impact is not significant. While same-period recurrent outlays on health have a positive impact on growth, the impact is also insignificant.

However, in the case of recurrent spending on transportation and communication, as well as previous defense spending, both appear to be the only significant contributions to the economy. Previous spending on defense, education, health and transport and communication all have an insignificant impact the growth of the economy.

Interestingly, the ECM coefficient of -0.15 for model two is the same with that of model one. The difference is the significant nature of the coefficient in model two. The coefficient value shows that an annual correction of about 15 percent takes place in the economy in the presence of distortion to long run equilibrium. This means for long run equilibrium to be restored in the economy as a result of policy and political distortions, it would take about six years and seven months for the effect of the distortion to be neutralized or erased

\subsubsection{Model Two Residual Hypothesis Test}

\section{Model Two Normality Test}




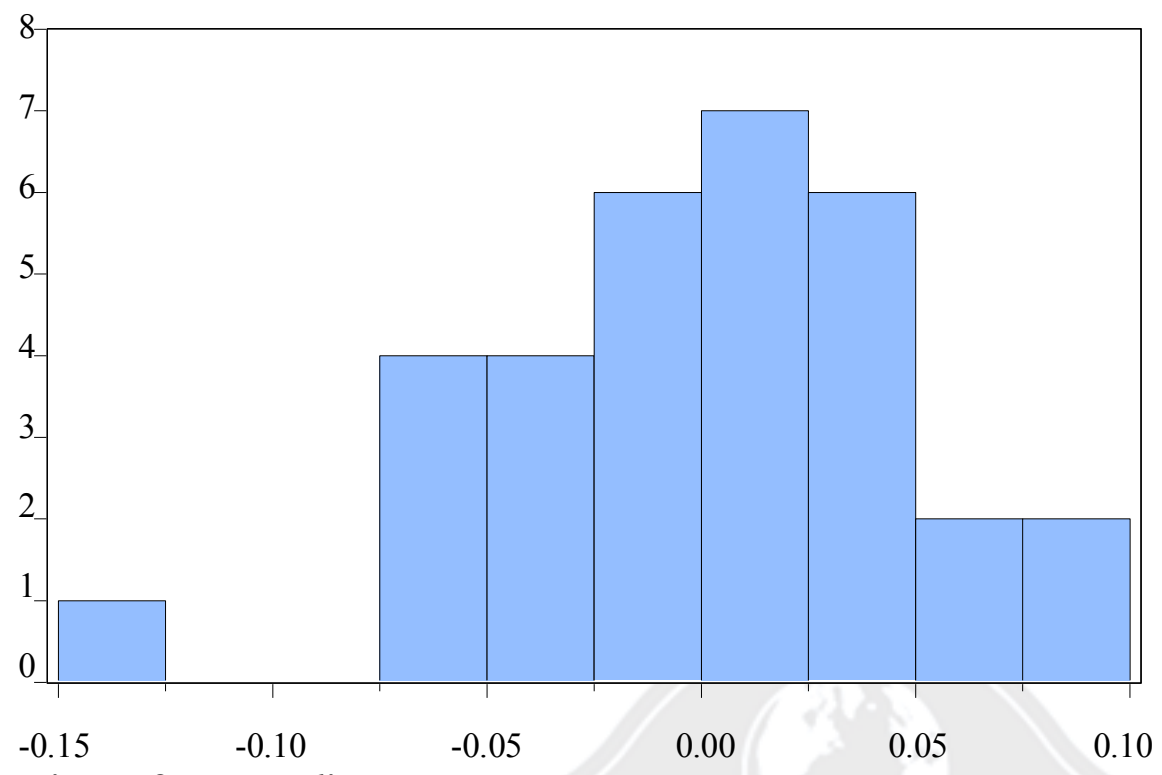

Series: Residuals

Sample 19832014

Observations 32

Mean

$-7.59 \mathrm{e}-18$

Median

0.010032

Maximum

0.098378

Minimum $\quad-0.128041$

Std. Dev. $\quad 0.050354$

Skewness $\quad-0.308039$

Kurtosis $\quad 2.930840$

Jarque-Bera $\quad 0.512449$

Probability $\quad 0.773968$

Figure 8: Normality Tes

Source: Computed by Authors from Eviews Output

The residual normality test for model two above accepts the null hypothesis that the residuals for model one is normally distributed.

Model Two Serial Correlation Test

Table 12: Breusch-Godfrey Serial Correlation LM Test:

\begin{tabular}{l|l|l|l|}
\hline F-statistic & 0.463058 & Prob. F(2,17) & 0.6371 \\
\hline Obs*R-squared & 1.653214 & Prob. Chi-Square(2) & 0.4375
\end{tabular}

Source: Computed by Authors from Eviews Output

Likewise, the serial correlation test for model one also accepts the null hypothesis of no serial correlation in the residuals.

\section{Model Two Heteroscedasticity Test}

Table 13: Heteroskedasticity Test: Breusch-Pagan-Godfrey
F-statistic
0.922180 Prob. F(12,19)
0.5449
Obs*R-squared
11.77793 Prob. Chi-Square(12)
0.4637
Scaled explained SS
4.008598 Prob. Chi-Square(12)
0.9833

Source: Computed by Authors from Eviews Output 
In line with the above tests (accepting the null hypotheses) and judging by the probability value of the observed R-squared; the residuals for model one show that they are homoscedastic in nature.
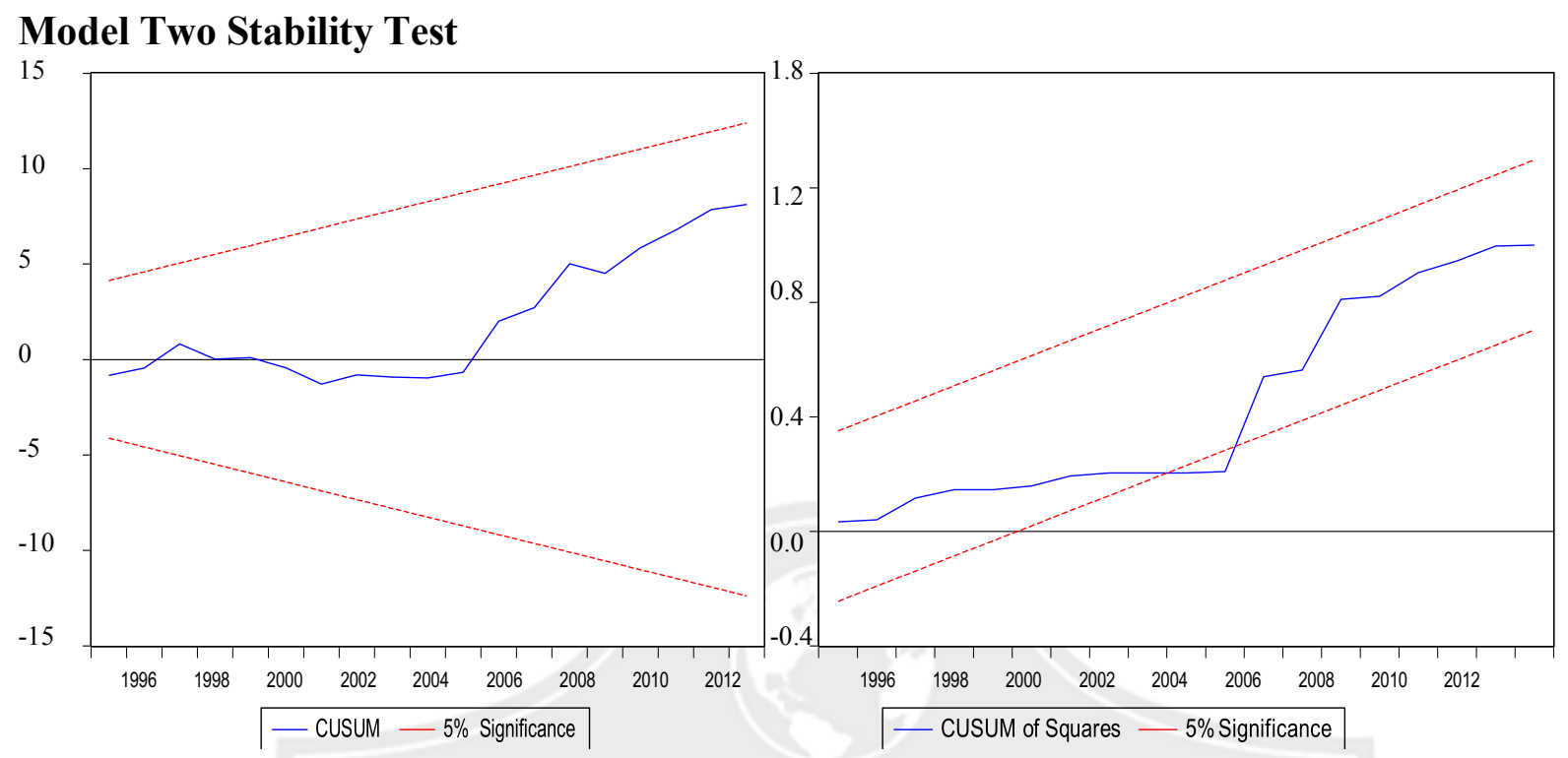

Figure 9: Residual stability Test

Source: Computed by Authors from Eviews Output

The residual stability test for cumulative sum and cumulative sum squared shows that the residuals are stable at the five percent significance level.

\section{CONCLUSION}

This study concentrated on analyzing the short run impact of government capital and recurrent outlays on key growth driving sectors for the period 1981 to 2014 in Nigeria. The study found that current government capital spending in the education sector has been a positive contributor to growth, compared to its recurrent spending. The same scenario was observed in the agricultural sector, as well as past capital outlays on the transport and communication sector.

However, an inverse effect on the economy was found for current capital outlays on defense and previous spending on agriculture, education and health sectors. These trends can be attributed to the rates of abandoned projects which are common in these sectors due to poor funding of capital projects, coupled with the problem of sustainability of previous governments' projects by incumbent governments. We believe these trends are undesirable if the country aims to attain its vision 2020:20. That is, the goal of being one of the twenty most industrialized countries in the world.

The recurrent outlays in the five sectors being examined show inverse impact on economic growth, with exception to previous spending on defense, and transport and communication. Aside from these two sectors, though the regression output shows that the impacts are not significant, growth in recurrent outlays should be controlled by the government, because they crowd out of funds for capital spending. 
The five sectors being considered in this study, if properly harnessed, are endowed with the potential of creating much needed jobs in the economy, capable of stimulating its path into prosperity. They also have the ability to raise the productivity level of the economy, and to improve the standard of living of the citizens.

\section{RECOMMENDATIONS}

Based on the above conclusions, we propose the following recommendations:

The educational sector plays an important role in the provision of quality manpower for the other sectors of the economy. For a nation to actually grow, the possession of qualified human resources is quite essential. That said, the government's increased recurrent spending in the sector will not yield this required labor force. Rather, increased capital spending in the form of building and equipping existing laboratories in various institutions of learning, as well as construction and rehabilitation of existing schools (primary, secondary and tertiary institutions) is required. Capital spending aimed at encouraging Research and Development in the tertiary institutions should be increased and disbursed adequately for such a purpose.

The health sector is also critically linked to the continuous general well-being of the work force. The observed scenario of increased recurrent outlay over capital spending is also undesirable. Improved investment in capital projects should be given more emphasis, because a better health sector would help reduce the rather large amount of foreign exchange being lost by the economy due to increasing demand for quality health care abroad. If proper capital investment in the sector is being done, the country stands to benefit from foreign capital flow realizable from the sector.

The transport and communication sector is very much important to the growth process of the Nigerian economy. Obviously, if the government is to achieve its vision of becoming one of the most industrialized nations, then capital investment in this sector would play a major factor at realizing this goal. This is because a good transport and communication system not only directly adds value to the GDP, but also helps in the supply chain of goods and services from the manufacturing sector to the end users. Poor transportation and communication also contribute to the high cost of production responsible for the weak competitiveness of goods produced within the country, in the form of high prices. The recent attempt by the government at improving the output of this sector in recent years through special intervention schemes, et cetera, is commendable.

Investment in the defense sector today has been considered by most nations to also be necessary, just as in the electrical and agricultural sectors. This is owing to the rising security threat to life and investments in most countries. Thus, the government's improved capital investment in the sector is strongly recommended to ensure investors' confidence in the safety of their investments throughout the country. Increased capital spending in acquisition of modern military hardware, as well as the training and retraining of military personnel with the most recent anti-terrorism techniques are all required. Additionally, the Defense Industries Corporation should be revitalized because of its potential of creating additional jobs in the economy, and of saving the economy of foreign currencies used in the purchase of military hardware, which creates jobs in those countries where such hardware is being imported from, at the expense of the local economy. 
The agricultural sector is one which can conveniently rival the oil sector, which is currently acting as the main "life line" of the Nigerian economy. Increase in capital spending in the agricultural sector over recurrent spending should be sustained. This would enable the sector function efficiently as a producer of industrial raw material to the manufacturing sector, reduce unemployment among youths, guarantee food security for the nation, serve as source of reliable foreign earnings for the country, and so on.

Finally, the interdependence of these sectors could help ensure the speedy economic and social transformation essential in attaining sustainable growth and development of the Nigerian economy. This is because in each sector abounds with huge growth potentials; thus, the need for sustainable investment to ensure they help realize the growing needs of the economy.

\section{REFERENCES}

Adesola, S.M. (1995). Income Tax Law and Administration in Nigeria. Ibadan, College Press limited

B.O. Iganiga \& D.O Unemhilin (2011) The Impact of Federal Government Agricultural Expenditure on Agricultural output in Nigeria

Central Bank of Nigeria (2014): CBN Statistical Bulletin. Abuja, Nigeria.

Emeka O.M. (2007): Improving the agricultural sector toward economic development and poverty reduction in Nigeria. CBN Bullion, 4: 23-56.

Hincliffe K. (2002): Public Expenditure on Education in Nigeria: Issues, Estimates and some Implications. African Region Human Development Report Working Paper Series. The World Bank, Washington D.C.

Josaphat, P. K and Oliver M (2000). Government Spending and Economic Growth in Tanzania, 1965-996: CREDIT Research Paper.

Koven. S. G and Lyons. T. S (2003). “Tools of Economic Development”. Economic Development Strategies for state and local Practice. New York: ICMA- Management Association.

Maku O. E (2014). Public Expenditure and Economic Growth Nexus in Nigeria: a time series analysis. Public Policy and Administration Research. Vol. 4, No 7.

Nigeria Project Agenda (2007). Nigeria Project and shared aspiration. Available via the internetathttp://siteresources.worldbank.org/NIGERIAEXTN/Resources/7Point s_policy_Nigeria.pdf

Niloy, B., Emranul. M.H and Denise. R.O (2003). Public Expenditure and Economic Growth: A Disaggregated Analysis for Developing Countries, JEL, Publication.

Obasanjo M.A. (2006). Budget Speech: Federal Republic of Nigeria.

Okonjo-Iweala, N. and P. Osafo-Kwaako (2007): Nigeria economic reforms. Progress and challenges. Brookings Global Economy and Development. The Brookings Institution. 1775 Massachusetts Avenue, Washington D.C. 20036.

Robinson M.O, Eravwoke K.E and Ukavwe A. (2014). Government Expenditure and Economic Growth: the Nigerian experience. Mediterranean Journal of Social Sciences. Vol. 5 No 10.

World Bank (2000): The quality of growth. Research Department, World Bank, Washington D.C. 